\title{
Creation of Ethnicity in an Early Christian Document: The Epistle to Diognetus
}

\author{
Amanda Nelson
}

\begin{abstract}
Second century documents such as the Epistle to Diognetus can give us an insight into the creation of identity when Christianity was just starting to flourish. This study uses definitions of identity from the perspective of several scholars such as Jonathan Z. Smith and Denise Kimber Buell, as well as others. The aim of this work is to understand how identity was imagined in one important early Christian document.
\end{abstract}

Previously, scholars have felt that early Christian documents did not demonstrate ethnicity, race and religiosity as complementary concepts. ${ }^{1}$ Instead, they interpreted the universality of early Christianity as a new race, one that "transcends or dissolves ethnoracial difference."2 Early Christian writers helped to create a new identity for the Christian group by constructing new distinctions that implied universal membership to a transcendent realm. But this did not mean that the Christians felt that they were detached from this world. The sense of social dislocation in these texts reached out to the common citizen experiencing the same sense of insecurity in an ever-changing Greek and Roman society. New scholarship shows the language in these documents was not so different than language commonly describing ethnicity and identity during this period. ${ }^{3}$ For example, literary devices in these texts which declared the Christians 'citizens of Heaven' could have been the first steps in providing the new Christians with an imaginary link to a rather distant God. Other groups established connections with the divine through different methods. Jewish people created this link through sacrifice while polytheistic Greeks communed with the gods through worship of physical objects.

The Epistle to Diognetus is an example of an early Christian document creating links to divine citizenship; it is highly praised for its "clear argument and intent." 4 The Epistle is a neat little apology written sometime in the mid to late second-century - that is, an apology defending the Christian faith. ${ }^{5}$ Scholars have searched through this text to find clues to elucidate authorship and its date of origin. One scholar suggests that the author might be Hippolytus

\footnotetext{
${ }^{1}$ Denise Kimber Buell, Why This New Race: Ethnic Reasoning in Early Christianity (Columbia University Press: New York, 2005), 137-8.

2 Buell, Why This New Race, 35.

${ }^{3}$ Buell, for example, states that "when early Christians claim that their distinctiveness is the ideal culmination of humanity, they are not unique - Romans and Greeks regularly make such claims as well." Why this New Race, 152.

${ }^{4}$ Roberts-Donaldson, "Introductory Note to the Epistle of Mathetes to Diognetus," Christian Classics Ethereal Library, www.ccel.org/ccel/schaff/anf01.iii.i.html, accessed April 23, 2011.

5 Kevin Knight, "Epistle to Diognetus," New Advent Catholic Encyclopedia, www.newadvent.org/cathen/05008b.htm, accessed April 23, 2011.
}

\section{Constellations}

Volume 2, No. 2 (Winter 2011) 
of Rome (c. 170- c. 235). ${ }^{6}$ Others have suggested Justin Martyr as the author, or one of the other apostolic fathers. ${ }^{7}$ While it was once placed with the writings of the apostolic fathers of Irenaeus, Tertullian, Origen, among others, authorship is now situated later than the apostles of Jesus' time. ${ }^{8}$ This paper will not be a survey of literature of the apostolic fathers, nor will I take into consideration the vast sources of archaeological data available for understanding group and individual identity in $2^{\text {nd }}$-century Greece or elsewhere. This will be an in depth analysis of the Epistle in order to understand how an anonymous author imagined and expressed Christian identity.

With regards to its intended audience, most scholars agree that the "most esteemed Diognetus" could be either an esteemed person holding that title, or more specifically, the tutor to Marcus Aurelius, Emperor of Rome.' The Epistle to Diognetus sets out to answer questions posed by Diognetus: what was "the mode of worshipping God prevalent among the Christians... what God they trust[ed] in, and what form of religion they observe[d]." "10 The epistle responded to these questions in the first ten chapters. Most scholars who have studied the epistle agree that the final two chapters bear little relation to the body of the document and may have been added at a later date. The Epistle is organized as follows. Chapter one acts as an introduction to the rest of the letter, recasting Diognetus' questions and providing a brief summary of their responses. Chapter two addressed the issue of idol worship among the gentiles, and we can see how the Christians have started to distinguish themselves through the author's criticism of this kind of worship. This division is widened further in the next two chapters which dealt with the superstitions and other observances of the Jews. The author to the Epistle showed a kind of sadness at the belief that the Jews had strayed from the 'true' path, and dismissed their strict diets, body modifications, and rituals as something not worth discussing further. ${ }^{11}$ The following five chapters, not including the last two chapters of doubtful origins, discuss the manner of the Christians: the things they share with each other and how they differ with the rest of the world; the relationship they have with that world; and why it took so long for God to send his son. The last two chapters change in tone and in subject. They discuss the importance of 'knowledge' of the father, and the importance of believing in the Word (quite possibly referring to the gospels) and that God sent his son to teach the world.

The date and authorship of the Epistle can only be interpreted through literary analysis. Although Diognetus is generally placed with the Apostolic Fathers of the second century, certain terms and comments imply that the writer possibly lived before the Apostolic Age in

6 R.H. Connolly, Rev, OSB, "The Date and Authorship of the Epistle to Diognetus," Journal of Theological Studies, 36 (1935), 347.

${ }^{7}$ Connolly, "The Date and Authorship of the Epistle to Diognetus," 347.

${ }^{8}$ Jeffery s. Siker, "Christianity in the Second and Third Centuries," in Early Christian World Volume 1, by Philip Francis Elser (Routledge: London and New York), 232.

${ }^{9}$ Roberts-Donaldson, "Introductory Note."

10 "Diognetus" Chapter 1, line 1

11 "Diognetus" Chapter 2 he says, "I might easily find many other things to say; but if even what has been said does not seem to any one sufficient, I deem it idle to say anything further." 
the early second century. ${ }^{12}$ It is amazing that this text made it to the modern age. It comes to us from the preservation of "a single, imperfect manuscript from the thirteenth or fourteenth century." 13 The ownership changed until the $19^{\text {th }}$ century when it settled in the Strassburg library. Only three copies had been made of this document since the $16^{\text {th }}$ century, and luckily too, for the library at Strassburg where it was housed in burned down in 1870 during the Franco-German War. ${ }^{14}$

Until recently, most of the scholarly focus has centred on discovering the correct date and authorship of the Epistle. Now, scholars are starting to analyze fully the content of the document and understand the circumstances that led to its creation and the implications it may have had for the early Christian community. For example, scholar Bryan C. Hollan uses rhetorical analysis to explain why it is assumed to be an early example of an apologetic letter. He suggests that the intended audience could be a curious non-Christian, or it could be addressed to the Christian community as "edification for a community struggling to make its way in an inhospitable culture." 15 This would explain the lack of description of Christian practices - the audience could already be aware of the details. If the intended recipient was Diognetus, the tutor of Marcus Aurelius, hiding the details would have been a safety precaution. Marcus obviously felt threatened by the Christian community. By remaining silent about details of specific rituals or prayers, the author of the epistle could protect the Christian community from detection. ${ }^{16}$

\section{Racial and Ethnic Identity in the Epistle}

New studies of identity have significantly changed since the racial theories of World War II. Rather than seeking to define someone or a group by their physical characteristics, scholars like Jonathan Hall seek to realign anthropological thought to ethnic identity. ${ }^{17}$ Hall defines ethnic identity as "the operation of socially dynamic relationships which are constructed on the basis of a putative shared ancestral heritage." 18 How does this relate to the Epistle? The author of the Epistle to Diognetus chose to ignore the role that descent plays in ethnicity. Instead, he placed emphasis on heavenly citizenship: "But, inhabiting Greek as well as barbarian cities... [t] hey dwell in their own countries, but simply as sojourners ... they are citizens of heaven." 19 In the following chapter of the Epistle, the author continued to describe the Christian relationship with the world, emphasizing that their inherited territory was not on earth. The Epistle also emphasized the perseverance of the Christians to love all

\footnotetext{
12 Roberts-Donaldson, "Introductory Note."

13 Hollan, "Is the Epistle to Diognetus an Apology," 127.

${ }^{14}$ Hollan, "Is the Epistle to Diognetus an Apology," 128.

15 Hollan, "Is the Epistle to Diognetus an Apology," 131.

${ }^{16}$ Esler, Early Christian World, (Routledge, 2000), 244.

${ }^{17}$ Jonathan M. Hall, Ethnic Identity in Greek Antiquity, (Cambridge University Press, 1997), 15-16.

${ }^{18}$ Hall, Ethnic Identity, 16.

19 "Diognetus," Chapter 5.
} 
despite persecution and accusations. For example, the author of Diognetus stated: "They love all men, and are persecuted by all... they are put to death and restored to life."20

What was it that held these early Christians together, separated as they were by language, culture and distance? Was it the tendency to use the vernacular instead of an exclusive script? Scholar Adrian Hastings suggests that later Christians were attracted to Christianity because of the various translations of the Bible into their language. ${ }^{21}$ From its creation to present day, Christianity has made itself available to the average person from any social level and background. Also tied to vernacular was the open description of the Christians as a holy, yet persecuted group. Hastings says "the whole concept of a 'Holy People', divinely chosen but enduring all the ups and downs of a confusing history, seems so very applicable to life nearer home." ${ }_{22}$ The literary technique of identifying the Christians as a new social group, in addition to the Greek, Roman or Jewish ethnicities already present, helped new members firmly establish a sense of identity within a society dependent on secure status. As Judith Perkins finds in her study of early Christian identity, "the perception of Christians as a distinctly separate group, as discrete and self-contained, is a function of Christian selfrepresentation." ${ }^{23}$ In other words, the creation and maintenance of early Christian identity depended on these types of literary tools.

By the beginning of the second century, the division between the Jews and the Christians had grown. Christians used the Jewish scriptures to trace their heritage; however, in epistles such as this one, the Christians established themselves in the world as a new and- by virtue of their spiritual heritage-legitimate race. ${ }^{24}$ The author of Diognetus still carried some of the old sentiment that wished the Jews would correct their ways by describing them as superstitious and incorrect in their worship of God. However, the author half-heartedly amended his accusations, stating "if they abstain from the kind of service above described, and deem it proper to worship one God as being Lord of all, [are right]" 25 (brackets original). In this case, he reluctantly admitted the Jews worship the same God as the Christians, but that they simply worshiped him incorrectly sometimes.

\section{Defining Identity}

Defining concepts such as identity or ethnicity is difficult, and finding it in early sources such as the Epistle does not come easily. I will explore three different versions of identity and ethnicity and apply them to the Epistle: those of the scholars Jonathan Z. Smith, Denise Kimber Buell and Per Jansson.

\footnotetext{
20 "Diognetus," Chapter 5.

21 Adrian Hastings, The Construction of Nationhood: Ethnicity, Religion and Nationalism, (Cambridge University Press, 1997), 194.

22 Hastings, Constructions of Nationhood 197.

${ }^{23}$ Judith Perkins, New Identities: Pagan and Christian Narrative from the Roman Empire, (Routledge, Abingdon, UK., 2007), 32.

${ }^{24}$ Siker, "Christianity in the Second and Third Centuries," 232.

25 "Diognetus," Chapter 3.
} 
Per Jansson creates a definition of collective identities through the study of Thucydides' "History of the Peloponnesian War." He concludes that, unlike the theories during the and after World War II, ethnicities [were] socially created and are based on the differences between 'us' and 'them:'

First, it is often claimed that collective identities are not naturally generated but socially constructed... Second, it is frequently suggested that the process of identity construction entails demarcation towards the environment of the subject, indeed, identity is said to be created by the indication of differences in relation to 'the Other'... ${ }^{26}$ (italics original)

The author of Diognetus created group identity based on the demarcation of 'the Other' in terms of religious practices. This allowed for fluidity in identity rather than a static, unchanging definition of how the Christians view themselves or where they placed themselves physically in the world. The author broke down the physical barriers identifying a Christian from the rest such as location, customs, and language. He stated that only Christians' patient and loving behaviour could identify them from the 'Other'. Before God made himself known, explained the author, "He permitted us to be borne along by unruly impulses, being drawn away by the desire of pleasure and various lusts." 27 After God made himself known to those who listened, Christians were bound together by the knowledge passed from God's only son. This belief in Christ as the Messiah is the essential characteristic of Christianity. It also justified the break Christians made with Judaism. This claim of 'knowing God' was one of the ideological concepts binding the Christians together in place of physical demarcations. These beliefs were the socially constructed markers that defined Christianness.

There were several other ways in which early Christian identity was created. It can be shown that the author of the Epistle defines the 'Other' in terms set out by the scholar Jonathan Z. Smith. First, he describes the metonymical model, in which the 'Other' is described using words "in which an attribute of something is used to stand for the thing itself." It is used to describe 'them' or 'the other' by pointing out specific cultural traits that are different than those of the Christians. ${ }^{28}$ Smith illustrates this type of description through the tendency of one culture to expand or exaggerate a difference in the other culture, for example, calling another group a 'fish-eater' or labelling them on the basis of some physical feature. ${ }^{29}$ In this case, the author of the Epistle made it clear that he perceived the Jews as different because of their 'superstitions,' in their constant observations of the planets and stars, and in their refusal to eat certain meats. ${ }^{30}$ The author of Diognetus noted that Christians as a group

\footnotetext{
26 Per Jansson, “Identity-defining Practices in Thucydides' History of the Peloponnesian War," European Journal of International Relations 3(1997), 149.

27 "Diognetus," Chapter 9.

28 Jonathan Z. Smith, "Differential Equations on Constructing the Other," in Relating Religion: Essays In the Study of Religion, Jonathan Z. Smith (University of Chicago Press, Chicago and London, 2004), 231-2.

29 Smith, "Differential Equations," 232.

30 "Diognetus," Chapter 4.
} 
believed these practices as erroneous. In terms of Jewish refusal to eat certain meats, the author stated "to accept some of those things which have been formed by God for the use of men as properly formed, and to reject others as useless and redundant, -- how can this be lawful?" 31 When speaking about the Gentiles, he focused on their habits of sacrificing to blind idols. The author explained the foolishness of such acts by stating "Let any one of you endure to have such things done to himself? But not a single human being will, unless compelled to it, endure such treatment, since he is endowed with sense and reason." 32

Smith outlines a second variation of describing the self and the other, one of centre and periphery. ${ }^{33}$ Smith describes this as a physical space designated for defence by a specific group. However, the author of Diognetus used this in a more imaginative way than usual. Rather than separated by distance or culture, the author suggested the Christians were separated ideologically. This allowed the group to accept all and sundry, and still be separate from those who chose not to join at an ideological level. For example, at the very beginning of chapter five, the narrator wrote, "for the Christians are distinguished from other men neither by country, nor language, nor the customs which they observe." 34 In the following chapter, he described the Christians as the soul of the body, and the world as the body holding the soul in against its will. ${ }^{35}$ Many scholars believe this imagery indicated the concept of a 'transcendent' race with regards to the Christians. ${ }^{36}$ Perhaps to the ancient reader, it would have simply implied an imaginatively closer relationship with a far-away God, or it could have given them a secure place and status (as a Christian) in a world which highly valued social, religious and civic status. The author of Diognetus created a space for any person based on these parameters; for those who with a lower social status, "they are dishonoured, and yet in their very dishonour are glorified;" 37 and for those seeking special

\footnotetext{
31 "Diognetus," Chapter 4.

32 "Diognetus," Chapter 2.

33 The third model that Smith describes is one in which the 'Other' is described intellectually and linguistically. In this model, which Smith suggests is far more "problematic and mischievous," and is "the only one of the three to be raised to the status of a modern theory." In this case the 'Other' is always and permanently different. As Smith states, "the 'Other' is unintelligible and will remain so." The Epistle tends to epitomize the main problem that Smith finds with this theory: it simply does not exist in this text. Nowhere in the Epistle does the author state or imply that any non-Christian, Jew or Gentile, speak such a different language that it is incomprehensible or incompatible with the Christians and their ideas. Out of the three, this "differential equation" is the only one that is not demonstrated within this text. Regardless of how one defines the 'Other,' it is simply another way of creating their own self or group identity. For further information, see Jonathan Z. Smith, "Differential Equations on Constructing the Other," in Relating Religion: Essays In the Study of Religion, Jonathan Z. Smith (University of Chicago Press, Chicago and London, 2004).

34 "Diognetus," Chapter 5.

35 "Diognetus," Chapter 6.

36 Buell, Why This New Race, 1. Buell names three scholars who have suggested that early Christians eschewed ethnic terms and reasoning “... as a condition of religious identity". They are Classicist Frank Snowden Jr., Anthony Smith, and feminist theologian Rosemary Radford Reuther and Guy Stroumsa.

37 "Diognetus," Chapter 6.
} 
civic status, "they obey the prescribed laws, and at the same time surpass the laws by their lives." Scholar Denise Kimber Buell, in her study of Christian identity states that this defining feature [citizenship] makes it possible to portray Christianness in at least partially universalizing terms-as an identity that, like other forms of citizenship, is potentially accessible to all free male people, something that sets Christianity apart yet allows them to otherwise "fit" into the status quo. ${ }^{39}$

While customs, language and territory are dismissed as identity markers in Diognetus, describing religious practice with undertones of citizenship was essential to the early Christian identity. ${ }^{40}$ All of these factors combine to create a new identity based on religion, encompassing the cultural and social preoccupations of the time.

In order to explore group identity formation in the Epistle, I used a study of Thucydides' "Peloponnesian War" by Per Jansson. While Thucydides wrote his work about 500 years before the Epistle, I use this work because Jansson creates a stable theory of collective identity applicable to my own study. He adopts an approach "which emphasizes the role of discourse and representation in creating and supporting notions of collective identity." 41 Early Christians took advantage of writing as a way to illustrate and defend Christian identity. Text was useful in explaining to followers how to lead a Christian life, and in this case, to explain to a non-Christian what Christianity was not. The author of the Epistle avoid explicitly defining Christians' religion and mode of worship by answering in the negative; he focused on oppositional criteria of what Christians were not. ${ }^{42}$ The Christians, according to the author, do not sacrifice to idols, nor do they believe in diet restriction, body modification, or observing the movement of the moon and stars. What they did believe in was positive and charitable behaviour towards everyone, even those who sought to harm them. The descriptions set the Christians apart as those loving people who were constantly persecuted, and the 'Other' as one who, for no apparent reason, hates them and seeks to destroy them. This tactic helped to reinforce the bond of religious commonality Christians shared, strengthening their resolve to maintain the faith. Because Christianity at this time was still in its infancy and not yet state-protected religion, commonality was necessary to cement the blossoming Christian community; even simply being kind to a neighbour established common characteristics, helping early Christians to feel connected.

Christian identity is often thought to be unique among groups for various reasons. However, we must be cautious when comparing historical identity to modern identity. Although the question "who am I?" remains stable throughout time, responses vary across the ages. Christian identity, historical and modern, has claimed to set itself apart from other religious and secular identities, defining themselves as 'God's children' and 'citizens of heaven, not of

\footnotetext{
38 "Diognetus," Chapter 6.

39 Buell, Why This New Race, 31.

40 Buell, Why This New Race, 31.

41 Jansson, "Identity-defining Practices in Thucydides," 148.

42 "Diognetus" Chapter 1.
} 
earth.' Jonathan Hall states that "the ethnic group is not a biological group but a social group, distinguished from other collectivities by its subscription to a putative myth of shared descent and kinship and by its association with a 'primordial' territory. ${ }^{43}$ However, Buell has it right when concluding that the early Christian writings, especially Diognetus do not conform to this definition. She states:

The narrator's framing indicates that language, customs, and place of residence (if not origin) are among the accepted means of distinguishing people from one another. Nonetheless, he or she insists that these categories fail to determine Christian difference. ${ }^{44}$

As mentioned above, the author of Diognetus based Christian identity on the social importance of citizenship manipulated through religious expression. Buell continues by saying that the Epistle was not the first to use this. Many earlier Christian works such as "Odes to Solomon, Hebrews, and 1 Peter," created a Christian identity through comparisons of religion "and citizenship $[, . .$.$] depicting Christians as foreigners or strangers in the world or$ as citizens of heaven." 45

Religious practice, concludes Buell, implies both a fluid and a fixed marker of ethnicity. ${ }^{46}$ The narrator of Diognetus demonstrated this through descriptions of Jewish and Greek religious practices. Identity was 'fixed' when a person or group's partook in particular religious practices. It was fluid when an individual or group changed their religious creed, ending practices associated with the previous form of worship and starting a new one. Buell uses the examples of the Israelites, defined as an ethnos (a people) in the book of Judith. They are described as descending from the Chaldeans. ${ }^{47}$ Israelites became a new group once they refused to worship in the same manner as their ancestors, moved, and began to worship in a new way. ${ }^{48}$ The Epistle describes the differences of the Greek and Jewish method of worship to enforce the idea that the Christians, who used to be either Greek or Jew or other, have now become their own ethnos. As Buell states, "[r]eligious practices and beliefs are thus among the factors that both embody [...] ethnoracial fixity and permit fluidity." 49

In Chapter two of the Epistle to Diognetus, the author asked the reader to free himself of prejudice, to lay aside all assumptions, and to become "the hearer of a new [system of] doctrine." 50 In this, the narrator challenged the reader to cast off traditional customs and beliefs in favour of a new belief system. Since the topic of discussion following this request is a critique of other worshipping practices, one can easily assume that the author is

\footnotetext{
43 Hall, Ethnic Identity, 2.

44 Buell, Why This New Race, 31.

45 Buell, Why This New Race, 32.

46 Buell, Why This New Race, 42-44.

47 Buell, Why This New Race, 43.

48 Buell, Why This New Race, 43.

49 Buell, Why This New Race, 43.

50 "Diognetus" Chapter 2.
} 
evangelizing to the reader, asking the reader to shift their identification from one group to another. This exemplifies Buell's conclusions regarding fluidity of identity through religious practices.

\section{Conclusion}

This paper has discussed three different ways of looking at ethnicity in an early Christian document. Jansson discusses how ethnicity was a socially created group effort; people created and understood their own identities through the demarcation of the 'Other' by focusing on differences between groups. Also, Jansson finds that group identity is strengthened through the recognition and affirmation "of the bonds that join the people together." 51 Group identity is also created through the use of what Smith calls the metonymical model. By illustrating the modes of worship among the Jews and Gentiles, the Christian group can create and reaffirm their own identity. While the Epistle to Diognetus can fall within the parameters set out by these two scholars, Buell has the most to offer in terms of studying early Christian identity. She shows that Christian identity construction is not unusual as most scholars previously believed. There is no conflict between race, ethnicity and religion as one would expect. ${ }^{52}$ Rather, early Christians advertised that anyone, from any background could become a full member. The authors of documents such as the Epistle to Diognetus embodied the typical understanding of ethnicity present in the early Greek and Roman period. The Epistle fully demonstrates the tendency to create ethnicity based on whatever factors the author found most applicable. ${ }^{53}$ In this case it was a civic status represented by a guaranteed citizenship in heaven. This, like other early Christian documents, also offered a secure and beneficial social status to those who felt the most insecure and those who felt the need to belong to an inclusive group. They had the chance to 'transcend' the normal social boundaries, becoming a full member in a new divine citizenry.

51 Jansson, "Identity-defining Practices in Thucydides," 151.

52 Buell, Why This New Race, 139.

53 Buell, Why This New Race, 38. 


\section{Bibliography}

Buell, Denise Kimber. Why This New Race: Ethnic Reasoning in Early Christianity. New York: Columbia University Press. 2005.

Hall, Jonathan M. Ethnic Identity in Greek Antiquity. Cambridge: Cambridge University Press. 1997.

Hastings, Adrian. The Construction of Nationbood; Ethnicity, Religion and Nationalism. Cambridge: Cambridge University Press. 1997.

Hollan, Bryan C. "Is the Epistle to Diognetus an Apology? A Rhetorical Analysis." Journal of Communication and Religion 29, 1. 2005. 127-146.

Jansson, Per. "Identity-defining Practices in Thucydides': History of the Peloponnesian War." European Journal of International Relations 3. 1997. 147-165.

Perkins, Judith. "Cosmopolitan Identities." In New Identities: Pagan and Christian Narrative from the Roman Empire. London: Routledge. 2007. 17-44.

Siker, Jeffery S, "Christianity in the Second and Third Centuries." In Early Christian World Volume 1. Philip Francis Elser, ed. Routledge: London and New York. 2001. 231-257.

Smith, Jonathan Z. "Differential Equations on Constructing the Other." In Relating Religion: Essays in the Study of Religion. Chicago: University of Chicago Press. 2004. 230- 250. 